\title{
Sustained English lingua-cultural education: a solution for Ukraine
}

\author{
Oleg Tarnopolsky*, Nataliia Volkova, and Svitlana Kozhushko \\ Alfred Nobel University, 18, Sicheslavska Naberezhna Str., Dnipro, 49000, Ukraine
}

\begin{abstract}
Ukraine, as a state striving to join on the parity basis the international community of developed and democratic countries, lacks some important prerequisites for achieving this goal. Besides several economic and political factors making obstacles for the desired achievement, of no lesser importance are the humanitarian factors, such as the monolingualism and monoculturalism of a substantial part of Ukrainian population. They preclude unimpeded mutual understanding and mutual acceptance, as well as free unimpeded contacts, between many Ukrainian citizens and their European counterparts. In this aspect, the solution for Ukraine can be found in sustained foreign language lingua-cultural education of the broadest strata of Ukrainian population that could open for the people a way out in what concerns their ability to communicate freely and fluently all through the Western European space sharing with the people living there not only the language of international communication but also the cultural approaches and beliefs. The article discusses the ways of developing such sustained (life-long) English lingua-cultural education for the young generation of new Ukraine. It analyzes the section of that education to be implemented at Ukrainian nonlinguistic tertiary schools with the aim of designing its efficient model.
\end{abstract}

\section{Introduction}

Ukraine is a young and aspiring state that from the very first days of its independence has set itself the goal of leaving in the past the fetters of the Soviet regime and entering on the parity basis the community of developed and democratic countries of the world and first of all, the community of developed and democratic European countries.

Quite a number of obstacles lie in the way of achieving this goal - first of all, the economic and political ones, but those are beyond the scope of this article. We are concerned with the obstacles rooted in the humanitarian field, namely those that concern the issues of linguistic and cultural policies. The presence of such obstacles is the result of the fact that Ukraine is distinguished by monolingualism and monoculturalism of the majority of its population while the distinctive features of the European Union countries are multilingualism and multiculturalism which are officially considered as "the supporting pillars" of the Union's language and cultural policy $[1 ; 2 ; 3]$.

It would be wrong to say that Ukraine is a purely monolingual and monocultural society since UkrainianRussian bilingualism (or Russian-Ukrainian in the Eastern regions of the country) is all-pervasive and the features of Ukrainian and Russian cultures are sometimes so intermingled, due to historic causes, that their separation often becomes impossible or very hard even in theory. But this Ukrainian-Russian intermixture with its roots in the common past within the Russian Empire and the former Soviet Union is a very far cry from the multilingualism and multiculturalism of today's Europe. Both Ukrainian and Russian as Slavonic languages cannot serve as the intermediary languages in communication with the representatives of the Western European nations (whose languages mostly belong to the Germanic and Romanic families), and the culture and lifestyle of the Ukrainian people with their roots, as it has already been said, in the Soviet past are poor grounds for establishing mutual understanding with Western European counterparts.

This is why the solution of the humanitarian problem outlined above lies in foreign language lingua-cultural education of the broadest strata of Ukrainian population, the education with "the European vector," i.e. aimed at such language and culture training of Ukrainians that would bring their language development on a par with the language development of the citizens of the European Union and make their cultural development compatible with the cultural development of the citizens of the united Europe. Here it is worthwhile to remind that the European Union bases it language policy on the requirement for citizens of the united Europe to have a command of at least four languages: the language of the country where they permanently reside, the language of international communication (such as English), one more European language, and the regional (local) language as a safeguard against losing some less spread local languages and cultures, thereby impoverishing the cultural heritage of humanity as a whole $[1 ; 2 ; 3]$. Actually, what is meant here is sustained lingua-cultural education of European

Corresponding author: otarnopolsky@ukr.net 
citizens that would help them, while preserving their own linguistic and cultural identities, achieve penetration into, full acceptance of, and total tolerance towards linguistic and cultural identities of representatives of other linguacultural communities.

A similar sustained lingua-cultural education may and should be introduced in Ukraine but this is worth doing only in case if a truly efficient and all-embracing system of that education is developed. The goal of this article is to try and substantiate some fundamentals for creating such a system suggesting the prolegomena for its elaboration and an efficient model of a considerable section of the system - sustained English lingua-cultural training of non-linguistic university students in Ukraine.

\section{Sustained (life-long) lingua-cultural education of the young generation of new Ukraine: prolegomena for developing a sustained English lingua- cultural education system}

In fact, sustained lingua-cultural education system already exists in Ukraine, and it was developed and introduced in the very first years of its independence. But it concerns only one language and one culture - the Ukrainian language and culture $[4 ; 5 ; 6 ; 7]$. There is no doubt in the necessity of introducing such a system, especially in the Eastern and central parts of the country where centuries of Russian domination have led to almost total eradication of that language and culture. The system of sustained Ukrainian lingua-cultural education, though it cannot be considered as fully successful yet, nevertheless has started reversing the trend of de-ukrainization that was very prominent both in the times of tsarist Russia and the Soviet Union. Nowadays, Ukrainian language and culture are gaining grounds even in the regions of the country that have traditionally been Russian-speaking. Such success of ukrainization can be ascribed not only to legislative and promotional measures ( $\mathrm{TV}$, cinema, the legislative regulation of the use of Ukrainian in the media, etc.) but to sustained Ukrainian lingua-cultural education as well. Even a Ukrainian born in the Russian-speaking family environment cannot help learning Ukrainian and the Ukrainian culture because from the moment he or she joins the nursery school that language and culture is permanently taught to him or her: at primary, secondary, and high schools, in his/her university and post-graduate studies, and even (when he or she graduates) at work where the use of Ukrainian and not of Russian is becoming more and more an everyday occurrence, more and more spread, even in predominantly Russianspeaking regions.

The experience gained in Ukraine in developing the sustained Ukrainian lingua-cultural education and the sustained education in general (including the sustained Web-education [8]), as well as the experience of other countries in introducing language education for sustainable development [9], may and should be used in the elaboration of sustained English lingua-cultural education in Ukraine making such education life-long, just as the Ukrainian lingua-cultural education has become. The reasons for making English, among all foreign languages, the primary candidate for sustained (life-long) lingua-cultural education in Ukraine are quite obvious.

Not only is English more than just an international language, having become a planetary or global language of communication in today's world. It even ceases to be regarded as a foreign language in very many countries, where it is not the mother tongue of the population, turning into something that everyone has no choice but to be in command of because the lack of such a command is somewhat akin to illiteracy [10]. The current attitude to English is also colored by the fact that nowadays the lifestyle and everyday cultures of many developed countries are often modeled in many features in accordance with the lifestyle and everyday culture of the English-speaking nations, especially the USA. Therefore, a person having a good command of English and aware of the peculiarities of lifestyle and everyday culture of the English-speaking nations can feel himself or herself, if not at home, then, at least, quite comfortable almost everywhere in the developed and civilized world. Hence, the inevitable conclusion that all the new generation of Ukrainians must achieve a reasonably high (at least, the level B2 of an independent user [11]) command of English.

It is for achieving such a command and for improving it further that sustained (and even life-long) English lingua-cultural education is an absolute requirement for Ukraine. When this goal is achieved and English is spoken, written, and understood more or less fluently by the greatest majority of the Ukrainian population, the time will come for expanding the sustained foreign language lingua-cultural education system in the country. It will mean the inclusion of the second and maybe even third foreign languages into it (some attempts at such inclusion have already been made; however, as yet they are mostly successful at linguistic tertiary schools where future specialists in foreign languages are being trained). But now the crucial issue is how to make sustained (life-long) English lingua-cultural education an organic and integral part of the Ukrainian education system as a whole and how to make that part truly efficient.

It should be stated that sustained (life-long) English lingua-cultural education system is already in existence in the country. Children very often start learning English at a very young age at nursery schools/kindergartens and continue such learning at their primary, secondary, and high schools. The process is not interrupted in university education and even in postgraduate studies where courses of English are mostly mandatory. Even after that, English learning does not stop. The system of commercial English teaching to adults is quite developed in Ukraine, and this system is widely used (with greater or lesser success) by great numbers of adult people, up to quite an elderly age [12]. Consequently, in this country a person has all the opportunities of learning English from the earliest age and practically until quite an advanced age, so it may be safely said that a system of life-long (sustained) English teaching indeed functions. Another question is how successful that system is. Regretfully, the answer to this question is not 
infrequently negative because after years of studying English even the university graduates (to say nothing of school-leavers) often do not know the language well enough to use it effectively for international communication [12]. This lack of success in teaching and learning English does not spread to Ukrainian tertiary linguistic schools preparing specialists in English. There, the results are mostly quite adequate, so these educational institutions will not be analyzed further. But the other kinds of such institutions often suffer from the low level of English of their leavers and graduates.

There are many reasons for that, some of which are often beyond the control of teachers of English: the insufficiency of contact class hours with students (especially at non-linguistic higher schools); the lack of adequate modern equipment (such as computer laboratories specifically designed for language teaching) and of high quality modern (but often expensive) teaching and learning materials, and even the unwillingness of some students to invest a lot of efforts into English language learning though it cannot be said that really many of them do not understand the importance of such learning for themselves and are totally demotivated. But there are two others reasons for making students' language studies unsuccessful that the teachers can control, and controlling them can greatly increase the efficiency of language teaching and learning - so much so that it can even compensate for some of the above mentioned disadvantages.

The first of those reasons is the ineffective and obsolete teaching methods, some of them even dating to the Soviet times, that not a few teachers are still actively using (for instance, the grammar-translation approach). This does not promote optimization and intensification of language studies, not infrequently demotivating students, especially those who, even without such a factor, are reluctant to invest much time and efforts into learning English (see above). The other reason is the fact that very many teachers of English in Ukraine do not combine students' language studies with cultural studies in their courses. Culture is taught episodically, fragmentarily and mostly it is not the communication culture of the Englishspeaking nations which is absolutely crucial for successful communication in English. As a result, students command of English, even when they achieve it, is one-sided - linguistic but not socio-cultural which often precludes successful communication in English.

In the entire life-cycle of sustained English linguacultural education the two problems outlined above should primarily be solved on the level of sustained English lingua-cultural education at non-linguistic tertiary schools where English is taught for professional purposes. On the one hand, English education there is probably the most important and central one for all such life-long sustained education. If a graduate of a non-linguistic higher school graduates with a good command of English for professional use, he or she becomes a specialist able to practice his or her profession internationally and constantly improve the English professional communication skills in the course of that practice (further sustained practical education). If not, the student graduates only as a specialist of local value and his or her sustained English education mostly stops for good. Unfortunately, this is quite often the case, that is why improving and enhancing the quality of English studies at Ukrainian tertiary non-linguistic educational institutions is of decisive importance for the overall success of all the sustained English lingua-cultural education in Ukraine.

This was the reason why such improvement and enhancement of the quality of English courses at nonlinguistic tertiary schools were chosen as the subject matter of our article, and developing the relevant model and approaches was set as its aim. There were four of those approaches substantiated in our studies:

1. The principled pragmatism, or well-grounded eclectic approach to language teaching;

2. The constructivist approach based on experientialinteractive language learning;

3. The English language immersion in senior years of students' university studies;

4. The integrated 'language-and-culture' teaching and learning focusing on communication culture.

The following parts of the article are devoted to discussing these approaches with the aim of grounding them theoretically, elaborating the guidelines for their practical use, and analyzing what results can be expected from the introduction of these approaches.

\section{Principled pragmatism in English language teaching at non-linguistic tertiary schools in Ukraine}

Principled pragmatism was theoretically developed by B. Kumaravadivelu $[13 ; 14]$. He interpreted the principled pragmatism as the belief that there is no best method in language teaching, every existing method can contribute something useful to second/foreign language classroom practice, while practical teacher's ideas, reasoning and cognition, and not scholarly constructs, are crucial in shaping the content of everyday language teaching and learning and the ways of implementing such teaching and learning. This approach is called by us the well-grounded eclecticism because it presupposes uniting into one single approach the features of different, sometimes even contradictory, methodological approaches (eclecticism), but only those features that a teacher in his or her practical teaching can "weld" into a single and harmonious unity with no opposition between elements, so that the unity of those elements enhances the efficiency of teaching practice (well-grounded eclecticism).

Kumaravadivelu [14] saw the way to achieving such harmonious unity of features from different methodological approaches in pragmatically following 10 principles (principled pragmatism):

1. Maximizing learning opportunities;

2. Minimizing perceptual mismatches;

3. Facilitating negotiated interaction;

4. Promoting learner autonomy;

5. Fostering language awareness;

6. Activating intuitive heuristics;

7. Contextualizing linguistic input;

8. Integrating language skills;

9. Ensuring social relevance; 


\section{Raising cultural consciousness.}

What these principles signify and what should be done to observe them in the teaching practice will be discussed both below and in the following parts of this article devoted to the means of practically implementing principled pragmatism in language teaching. But, initially, in this part of it, it is worthwhile to consider how the concept of principled pragmatism per se benefits and enriches the sustained English lingua-cultural education at non-linguistic tertiary schools where English is taught for professional purposes.

First, it permits the teacher who is following the communicative approach to language teaching and learning (as every modern teacher does and should do) to have free recourse to the language-form focused learning activities (the non-communicative ones) that the strict communicative approach disapproves of and even considers as its opposites [15]. Such a free recourse is important because the total absence of form-focuing not only often worsens the overall learning outcomes [16;17] but may also demotivate adult learners, such as tertiary students, who frequently want and need first to analyze and process the language phenomena before they start using them fluently in communication. The opportunity of turning to language explanations and language formfocused activities whenever the teacher deems it desirable helps prevent some cases of students' demotivation, enhances learning outcomes, thereby contributing to successful sustained language education process. Besides, it fully meets the above principle of pragmatism/wellgrounded eclecticism requiring fostering language awareness, which means ensuring learners' better understanding of the language system. It is this better understanding which is the primary cause of the adult students' enhancement of learning outcomes already spoken about in this paragraph. Better understanding by students of the language system also helps prevent perceptual mismatches or, at least, minimize them (see the second principle of principled pragmatism above). The mismatches in question are the discrepancies between teacher's intentions and student's interpretations of those intentions, so that those discrepancies can cause the learning outcomes unexpected and undesirable for both the teacher and the learners. Language form-focused explanations prevent or minimize such mismatches, again enhancing learning outcomes and learners' motivation in sustained English language education.

Second, by its very essence the principled pragmatic approach requires that the teacher turns to all possible sources in search of teaching and learning resources and opportunities. For instance, those resources and opportunities can be found on the Internet, and the teacher can use them not only himself/herself for obtaining new additional teaching/learning materials and learning tasks for use in the classroom. He or she can also promote his/her students' out-of-class Internet search for finding learning information and for online learning of English in general. This requirement concerns in-class students' learning activities as well. They may and should be intensified and optimized by cooperative learning [18] when learning activities in class are mostly not teacherfronted but done in pairs and small groups. These and many other learning resources and opportunities that the principled pragmatic approach makes mandatory for use not only help compensate for some of the objective factors impeding the language learning process that in the preceding part of the article were mentioned as being beyond the teacher's control (for instance, out-of-class Internet learning compensates for the scarcity of in-class contact hours and lack of cutting-edge learning facilities and coursebooks). They, especially the online and cooperative learning, also make students' learning activities mostly autonomous [19] and safely autonomous because the teacher is always there - not so much as an instructor but as a facilitator [20], permanently ready to facilitate autonomous students' learning whenever there is a difficulty or obstacle. Such a "safe" learner autonomy, due to its highly independent and creative nature, cannot fail but to enhance the learning motivation, thus helping to solve one more objective problem in language teaching. The above-discussed compulsory way of implementing the principled pragmatic approach ensures the implementation of three of its principles as well, those of: maximizing learning opportunities (e.g., by way of using online learning), facilitating negotiated interaction in the target language (which is an inextricable feature of all kinds of cooperative learning), and, most importantly, promoting learner autonomy (see the explanations above).

Third, in what concerns the sustained English linguacultural education at tertiary non-linguistic schools, the future profession-oriented nature of such education makes it mandatory for the principled pragmatic approach to find practical support in all the latest developments in the area of English for Specific Purposes (ESP), i.e. teaching English for achieving purely professional goals [21]. One of the most prominent of such developments is contentbased instruction $[22 ; 23]$. It provides for "... the integration of content from the subjects of students' majors with the goals of target language teaching. It ensures parallel acquisition of knowledge from certain non-linguistic disciplines together with acquisition of the target language and the skills of communicating in it. In such instruction, the ESP curriculum is most closely linked or even based on the curricula of one or several of students' majoring disciplines so that learning the target language content follows the requirements of learning some professional content from the majoring disciplines through the medium of the target language. The development of students' target language communication skills proceeds mostly subconsciously through their learning in the target language the content matter from the majoring subjects. In this way, content-based instruction eliminates the gap between language learning and learning professional subjects ensuring students' learning the latter through the medium of the former." [24, p. 73]. Since principled pragmatism presupposes using everything that can help in achieving the learning goals if there is no opposition to or contradiction with the other parts and elements of the teaching/learning system, which may ruin its structure, - basing the principled pragmatic system of teaching English at tertiary non-linguistic schools on content-based instruction is inevitable. And this, in its turn, meets such principles of that pragmatism as contextualizing linguistic input (learning the language 
in the context of future profession) and ensuring social relevance (teaching and learning the language in direct connection with the social needs of training Englishproficient specialists in different fields).

Thus, after analyzing the fundamentals of the principled pragmatic/well-grounded eclectic approach, even without considering the practical ways of its implementation, it is revealed that when the approach is introduced into sustained English lingua-cultural education at tertiary non-linguistic schools, at least seven out of ten of its principles cannot fail but to be brought to life. These same principles and some others are brought to life as well if the principled pragmatic approach is implemented in teaching practice through constructivism based on experiential-interactive learning of English.

\section{The constructivist approach based on experiential-interactive language learning}

Constructivism in pedagogy $[25 ; 26]$ presupposes “... providing students with opportunities of "constructing" their own knowledge and skills through practical experience in real-life or modeled activities. In this case, students acquire their knowledge and skills as a byproduct of their real-life or modeled activities, thus internalizing (appropriating) the knowledge and skills and not just learning them" [24, p. 13]. From the quoted definition it can be seen how ideally compatible the constructivist approach is with principled pragmatism in language teaching and how ideally adapted it is to the sustained language education conditions. By imposing on students themselves the task to construct their own knowledge and skills, the constructivist approach puts into action eight out of the ten principles of principled pragmatism (see above) because: 1) the learning opportunities are automatically maximized since learners themselves maximize them to self-construct their knowledge and skills; 2) students minimize perceptual mismatches as they learn independently with the teacher as a facilitator, not an organizer or "explainer;" 3) they inevitably learn cooperatively, helping each other to achieve the common goal, i.e. through negotiated interaction among themselves (and with the teacher), being at the same time 4) highly autonomous in the process of this interaction; 5) learners' language awareness increases in the process of self-constructing their language knowledge and they are in constant need of 6) using intuitive heuristics in the process of knowledge and skill self-construction. Besides, since selfconstruction of language knowledge and communication skills is done through the content matter of future profession (see the preceding part of the article), 7) contextualizing the linguistic input and 8) providing its social relevance is ensured. It is clear that if such a mode of learning English is acquired and appropriated by students, it can and often will turn into their habitual behavior in such learning, i.e. the language self-education may become not only sustained, even after the language course at their higher non-linguistic school is finished, but also life-long.
Constructivism (as a theoretical foundation of a sustained foreign language course at tertiary nonlinguistic schools) in ESP teaching and learning practice is implemented only through the experiential and interactive (experiential-interactive) language learning system [24; 27]. When teaching ESP, or English for professional purposes, experiential learning is such an organization of the teaching/learning process which gives opportunities of constantly modeling the future specialists' professional activities in their language learning activities, so that the latter model the professional communication. What is specific for language learning is the fact that such quasi-professional communication is implemented not by the means of learners' mother tongue but by the means of their target language, thus allowing for the acquisition of the foreign language and communication skills mostly involuntarily and subconsciously as a by-product of modeled quasiprofessional activities and quasi-professional target language communication.

The research [24] has shown that experiential learning when teaching English for professional purposes at Ukrainian non-linguistic tertiary educational institutions means designing the teaching/learning process as an uninterrupted succession of specific professionallyoriented creative learning activities:

- role plays and simulations,

- students' brainstorming, case studies, discussions,

- presentations,

- workshops,

- learning projects,

- writing professional essays, abstracts, summaries, etc. in the target language.

All those activities can be successfully performed if they are constantly accompanied by out-of-class learners' autonomous search for information in the target language (mostly on professional Internet sites in English) and by processing the information found through reading and listening with the aim of providing sufficient professional data required for doing all the profession-oriented creative learning tasks above.

Even the listing of typical experiential learning activities given above makes clear two very important features of all of them. The first is that they are all interactive. Role plays/simulations, brainstorming, case studies, discussions, project work simply cannot be done individually - interaction in the target language with other students while working in pairs, small groups or even using the whole-class interaction pattern is the basic condition for organizing them. Presentations can be prepared individually (though quite expedient are presentations on some topic prepared by two or even three students), but they are always delivered in the interaction with the entire classroom of other learners. This is even more so when in experiential teaching and learning students' presentations are transformed into workshops where the presenters not so much present the information themselves as introduce the other students to the topic being discussed, give them tasks aimed at processing and achieving full understanding of that topic, monitor the students' performance, and finish the workshop by discussing the results and drawing conclusions. Even the 
experiential writing activities (see above) are interactive because they are done using the process approach [28] when every piece of students' writing is first outlined in small group discussions (team writing) and every individual writing draft is peer-reviewed and peercommented.

The information search and information processing (through reading and listening) activities done in experiential learning are also interactive though the search, reading, and listening themselves may be done totally individually (however, pair and small group work is quite possible in this case too). The interaction meant here is students' interaction with out-of-class sources of information - primarily, professional sources, like professional Internet sites in English used in ESP courses at non-linguistic tertiary schools for collecting information needed for completing creative experiential learning tasks, such as project work and the others.

Because of all this, it would be more accurate to speak about not experiential but experiential-interactive learning, as it has been done from the beginning of this article. Such deeply interactive and, consequently, cooperative (see the preceding part of the article) nature of experiential learning activities puts into action the best advantage of cooperative learning - peer-teaching because working in close cooperative interaction, students involuntarily share their personal stocks of knowledge, experience, and skills, thus teaching each other and learning from each other, which greatly enhances and improves the learning outcomes [18].

The second important common feature of all the experiential learning activities is integrating in them the development of the four basic language/communication skills: speaking, listening, reading, and writing. The experiential learning tasks are all creative, and, as it is clear from what was said above, doing them requires collecting information needed for their completing which means reading and listening in English. The tasks themselves are done through speaking or writing (and, quite frequently, first speaking and then writing, like in project work), while listening to other students reporting on their results in task completion is also included. So, the four communication skills become thoroughly intertwined since the communicative activities of speaking, listening, reading, and writing always follow each other in the consecutive and orderly manner, each receiving its fair share of attention. Not only does it help developing all the communicative skills in close unity/integration, which always ensures better results of such development [29], but it also meets the requirement of one of the important principles of Kumaravadivelu's principled pragmatism: integrated language skills [14].

At the beginning of this part of the article, it has already been said that the constructivist approach practically implemented in experiential-interactive learning activities perfectly fits and even follows the principled pragmatic approach and is highly compatible with the sustained English language education at a nonlinguistic higher educational institution. This latter compatibility is further reinforced by the fact that at such institutions a constructivist (experiential-interactive) course of English for professional purposes paves the road to English immersion in courses of professional disciplines in senior years of students' university studies. This issue is discussed below.

\section{The English language immersion in senior years of students' university studies}

The methodology of target language immersion $[30 ; 31]$ is based on teaching non-linguistic disciplines (mathematics, physics, history, tertiary school professional subjects, etc.) at secondary, high, or higher schools through the media of the second/foreign language to be acquired by students. Our research, including the experimental studies, has shown that at non-linguistic tertiary schools, if the course of English for professional purposes (which is usually taught in the first, second, and sometimes third years of university studies) is contentbased and designed as a constructivist/experientialinteractive one, students get fully prepared and ready to continue their English acquisition in English immersion courses that they start in the third, or the fourth at the latest, years of their university tuition [24].

In this case, the English immersion courses are regular courses on professional disciplines taught by Englishspeaking professors and teachers specializing in those disciplines, and these professors and teachers teach their subjects in English instead of learners' mother tongue. The conscious focus of attention is only on professional subject matter of the disciplines, while learners' command of English is being improved and advanced mostly involuntarily without any teacher and learners' concentration on language specifics in the process of tuition.

Our experimental research has demonstrated that, if the basic non-linguistic university course of ESP is taught as a totally content-based and constructivist (experientialinteractive) one, by the end of the second year of that regular English course students mostly achieve the B2 (independent user) level [11] in their command of the target language to be acquired for professional communication [32]. This ensures, as was also proved experimentally [33], a smooth transition, beginning from the third year of university studies, to introducing English immersion programs into courses of professional nonlinguistic disciplines. Such introduction is successful if it is graded and gradual - starting with the least difficult kind of immersion programs (preliminary immersion) in the third year, passing to more complicated and sophisticated but still somewhat simplified ones in the third and fourth years (partial immersion), and ending with entirely non-adapted total immersion programs in the final years of learners' university studies $[33 ; 34]$.

If such an approach is implemented, students frequently attain the $\mathrm{C} 1$ level [11] (a much higher one than is required by the curriculum and syllabi) in their mastery of English for professional purposes [33]. One of the most important reasons for such a success is the fact that following the suggested approach ensures a truly sustained English language education all through the years of learners' studies at their university: they begin 
acquiring English in their ESP course from the first year, learn it in that course in the second and, sometimes, third years, and from the third year smoothly proceed to English immersion in courses of special professional disciplines. Such immersion may continue until the end of university studies solving, though on the level of nonlinguistic higher schools only, the problem posed in Section 2 of this article - that of providing university graduates with sustained acquisition of English for professional communication. The suggested approach, by developing the means of solving the indicated problem on the level of one type of educational institutions, outlines the ways and means of solving it in a similar manner in all the other types of such institutions.

However, the approach developed by us has been discussed above in only one, though the most important, aspect of its implementation - that of ensuring sustained English language education. But in Section 2 of this article it was repeatedly emphasized that the sustained English lingua-cultural education is required. How the cultural constituent is superimposed on the elaborated approach is analyzed below.

\section{The integrated 'language-and-culture' teaching and learning focusing on communication culture}

Teaching culture, or socio-cultural competence, is an absolute prerequisite for learners to achieve the adequate development of their target language communicative competence, as it has already been said in this article and is repeatedly stressed in all the works regarding the development of such competence and learners' cultural adequacy in English communication [35; 36; 37; 38].

At higher non-linguistic educational institutions there is no opportunity of teaching target language community's culture in a special course, like "Language and Country Studies" taught at higher linguistic schools. Not only such a course is not included in the curriculum but also there is simply no time for it. Therefore, the only option is to superimpose the culture studies on the language studies both in the regular course of ESP and even in the English immersion courses on professional disciplines. For instance, if in the regular English course such experiential learning activities as students' discussions are organized, before they start, the teacher may tell the learners that in English formal discourse it is impolite to express direct and categorical disagreement with your interlocutor by saying: "You are wrong!" Only something milder is acceptable, like: "I agree with you up to a point, but on the other hand,..." Then, there may even be a short training task, after which the discussion proper will start. In a similar manner, in an English immersion course for students of Business and Economics when the ways and means of conducting business negotiations are discussed, the teacher should inform the students that in international business negotiations when an American businessman takes off his jacket and rolls up the sleeves of his shirt, it means that for him the preliminaries are over and he is ready to start talking business. But for a German businessman the implication is directly opposite: a desire to stop negotiating and relax for a while.

Such a manner of superimposing cultural information on ESP or English immersion courses does not require much time and efforts but keeps the cultural education sustained throughout those courses, simultaneously providing for the implementation of the last of Kumaravadivelu's principles [14] in the principled pragmatic approach - the principle of raising the learners' cultural consciousness. The latter ensures the complete implementation of this approach in all its aspects, which, in its turn, creates the required background for the efficient introduction of the constructivist/experientialinteractive approach.

Following such a mode of teaching the cultural constituent in sustained English lingua-cultural education allows learners to acquire all the cultural information that they really need for adequate professional communication in English but only on the condition that this information is properly and sparingly selected. Cultural information to be taught may be divided into two principal groups: the culture of the nation with a "big C" (literature, art, legislation, political structure of the country, etc.) and culture with a "small c," or communication culture, which can be either verbal or non-verbal [38]. It includes the cultural phenomena that make the communication culturally and socially acceptable in a given speech community [39; 40], which may be called the target language lingua-cultural community. The two examples of just such cultural information (both verbal and nonverbal) were given above, and it is only this last type of culture, restricted to strictly professional students' needs (their strictly professional communication in English), that should be taught at non-linguistic higher schools. Regretfully, the teachers of English not infrequently do something directly opposite - speak at length about English-speaking nations' "big C" cultures, so there is no time or opportunity left for teaching the really indispensable communication culture. Therefore, the contents of the cultural constituent of the sustained English lingua-cultural education at non-linguistic tertiary educational institutions should be selected as carefully (if not more carefully) than the language contents.

Everything said in this article leads to drawing some conclusions.

\section{Conclusion}

Ukraine, the country with the aspirations of becoming an integral part of Europe, urgently needs a system of ensuring the command of English as the language of global communication to the majority of its population, especially to the younger generations. Knowing the English language only is not enough, the culture of the English-speaking nations that has spread throughout all the developed countries in the world is of no lesser importance. It means the necessity of sustained (even lifelong) English lingua-cultural education. Ukraine already has an experience of organizing such an education after developing and putting into practice the system of sustained Ukrainian lingua-cultural education. This 
successful experience may and should be used for elaborating a similar system in what concerns teaching the English language and culture - as a preliminary to expanding that system to other foreign languages with the purpose of spreading multilingualism and multiculturalism among the broadest strata of the Ukrainian society,

The above article is devoted to discussing the development of the sustained English lingua-cultural education model for Ukrainian tertiary non-linguistic educational institutions with the aim of providing their students with the highest possible (up to $\mathrm{C} 1$ ) level of mastery of the English language and culture required for graduates' international professional communication. The elaborated sustained education model is based on four most important foundations when teaching English as a foreign language: the principled pragmatism, or wellgrounded eclecticism, in language teaching; the constructivist language learning implemented through experiential-interactive learning activities; the foreign language immersion, and the integrated 'language-andculture' teaching and learning focusing on communication culture. An important constituent of the model is its professional orientation towards the future graduates' professional needs in the language and culture of international communication. That orientation is brought to life, first, by way of introducing content-based instruction into the language course proper and, second, by way of designing English immersion programs for the courses of professional disciplines in the senior years.

All these components of the sustained English linguacultural education model are integrated, making a harmonious hierarchy shown in Fig. 1 below:

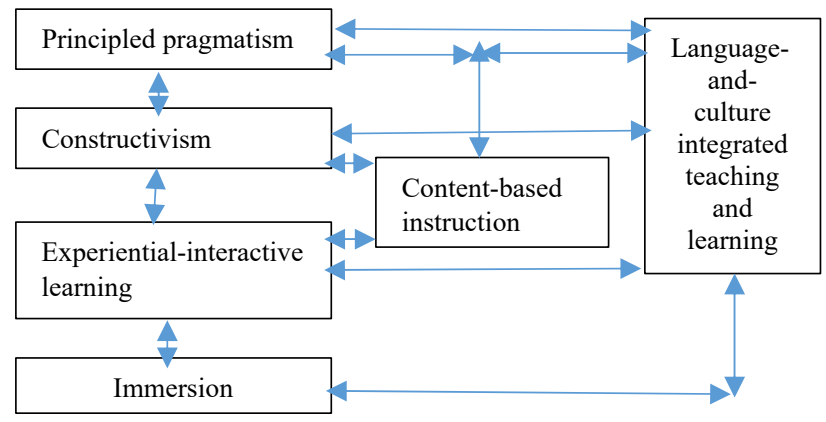

Fig. 1. Sustained English lingua-cultural education model for Ukrainian tertiary non-linguistic educational institutions

The introduction of the suggested sustained English lingua-cultural education system into Ukrainian tertiary non-linguistic educational institutions gives students an opportunity of achieving high levels of command of English for professional communication (as our experimental studies show, level B2 may be attained after the course of English [32] and level C1 after learning it in the English immersion programs [33]). Besides, such an introduction makes English language and culture education truly sustained - lasting all through the years of students' tuition at a non-linguistic higher school.

The prospects of further research in the same direction lie in attempting to expand the developed sustained English lingua-cultural education system to other types of educational institutions in Ukraine.

\section{References}

1. High Level Group of Multilingualism. Commission of the European Communities: Final Report (2007)

2. M.A. Korzhakova, Obrazovaniye i vospitaniye 9 (2010)

3. Language Planning and Policy in Europe, ed. by R.B. Baldauf, Jr., R.B. Kapla, 1-3 (2005)

4. Natsionalna doktryna rozvytku osvity Ukrainy u XXI stolitti (National Doctrine of Developing Education in Ukraine in the $21^{\text {st }}$ Century). (Osvita, Kyiv, 2001)

5. V.S. Isakova, Problemy y perspektyvy rozvytku bezperervnoi movnoi osvity v Ukraini (2015), http://osvita.ua/school/lessons_summary/education/4 5953/. Accessed 2 Mar 2020

6. V. Khymynets, Inovatsiina osvitnia diialnist. (Innovative Educational Activities). (Mandrivets, Ternopil, 2009)

7. Prohrama rozvytku i funktsionuvannia ukrainskoi movy v TDATU na 2016-2021 roky (The Program of Developing and Functioning of the Ukrainian Language in the TSATU for 2016-2020). (Melitopol, 2016)

8. S.V. Tytenko, Naukovi Visti NTUU "KPI" 5(61) (2008)

9. T. Zygmunt, Discourse and Communication for Sustainable Education 7(1) (2016)

10. D. Graddol, English Next. Why Global English May Mean the End of 'English as a Foreign Language', (2006)

11. Council of Europe. Common European Framework of Reference for Languages: Learning, Teaching and Assessment (Strasbourgh, 2001)

12. O. Tarnopolsky, Metodyka navchannya anglijskoyi movy doroslyh poza mezhamy universytetskyh movnyh program (Methods of Teaching English to Adults in Outside-University Language Programs). (Alfred Nobel University, Dnipro, 2017)

13. B. Kumaravadivelu, TESOL Quarterly 35, 4 (2001)

14. B. Kumaravadivelu, Beyond Methods: Macrostrategies in Language Teaching (Yale University Press, New Haven and London, 2003)

15. S.D. Krashen, Principles and Practice in Second Language Acquisition (Pergamon Press, Oxford, 1982)

16. R. Ellis, Instructed Second Language Acquisition: Learning in the Classroom (Basil Blackwell, Oxford, 1990)

17. S.S. Fotos, TESOL Quarterly 28, 2 (1994)

18. C. Kessler (ed.), Cooperative Language Learning: $A$ Teacher's Resource Book (Prentice Hall, Englewood Cliffs, 1992)

19. H. Holec, Autonomy and Foreign Language Learning (Pergamon, Oxford, 1981)

20. C.R. Rogers, Freedom to Learn for the 80s (Charles E. Merrill Publishing Company, Columbus, 1983) 
21. P.C. Robinson, ESP Today: A Practitioner's Guide (Prentice Hall, Hamel, Hempstead, 1991)

22. D. Brinton, M. Snow, M. Wesche, Content-Based Second Language Instruction (Newbury House Publishers, New York, 1989)

23. Encyclopedia of Language and Education, vol. 4 (Springer, New York, 2007)

24. O. Tarnopolsky, Constructivist Blended Learning Approach to Teaching English for Specific Purposes (Versita, London, 2012)

25. E. Glaserfeld, A constructivist approach to teaching, in Constructivism in Education, ed. by L.P. Steffe, J. Gale (1995)

26. V. Richardson, Teachers College Record 105, 9 (2003)

27. V. Kohonen, R. Jaatinen, P. Kaikkonen, J. Lehtovaara, Experiential learning in foreign language education (Routledge, New York, 2014)

28. R. White, V. Arndt, Process Writing (Longman, Harlow, 1991)

29. R. Oxford, Integrated skills in the ESL/EFL classroom. ERIC Digest, EDO-FL-01-05 (2001), http://www/cal.org/ericcll/0105oxford.html. Accessed 29 Sept 2006

30. French Immersion: Process, Product and Perspectives. The Canadian Modern Language Review (1994)

31. R.K. Johnson, M. Swain, Immersion Education: International Perspectives (Cambridge University Press, Cambridge, 1997)

32. O. Tarnopolsky, S. Kozhushko, Metodika obuchenija anglijskomu jazyku dlja delovogo obshhenija (Methods of Teaching English for Business Communication). (Lenvit, Kiev, 2004)

33. A.D. Vyselko, Dissertation, Kyiv, 2015

34. Z.M. Kornieva, Dissertation, Kyiv, 2006)

35. M. Byram, Teaching and Assessing Intercultural Communicative Competence (Multilingual Matters, Clevedon, 1997)

36. L. Damen, Culture Learning: The Fifth Dimension in the Language Classroom (Addison Wesley, Reading, 1987)

37. C.B. Paulston, Linguistic and Communicative Competence: Topics in ESL (Multilingual Matters, Clevedon, 1992)

38. O. Tarnopolsky, N. Sklyarenko, Lifestyle Communicative Behavioral Patterns in the USA (INKOS, Kyiv, 2003)

39. D.H. Hymes, On Communicative Competence. (University of Pennsylvania Press, Philadelphia, 1971)

40. R. Lado, Linguistics Across Cultures: Applied Linguistics for Language Teachers (University of Michigan Press, Ann Arbor, 1957) 